\title{
Feminist Örgüt Kuramları
}

\author{
Feminist Organization Theories
}

\author{
Dilek Çelik ${ }^{1 *}$ (D)
}

${ }^{1}$ Department of Political Science and Public Administration, Sirnak University, Sirnak, Turkey

\begin{abstract}
Received: 01.07 .2020
Accepted: 13.08.2020

This article was checked by intihal.net

ISSN: $2149-8598$

$\ddot{O} z$

Örgütsel çalışmalarda kadın, toplumsal cinsiyet ve cinsiyet ilişkilerine dair yaklaşımlar uzun süre göz ardı edilmiştir. Bu durumun temelinde, erkek egemen toplumsal yapının her alanda olduğu gibi örgütsel alanda da baskın olması yatmaktadır. Nitekim tarihsel süreçte toplum tarafından kadına yüklenen rollerin kadının çalışma yaşamına katılmasını zorlaştırması, örgütlerin oluşumunda ve yönetiminde çok büyük oranda erkeklerin yer almasına yol açmıştır. Dolayısıyla böyle bir yapı içerisinde örgütsel çalışmalar genel olarak erkek bakış açısıyla şekillenmiş ve daha çok hiyerarşi, güç ve yetki dağııımı gibi kavramlara odaklanmıştır. Cinsiyet ile ilişkili konular ise genellikle istatiksel verilere dayalı olarak ele alınmıştır. Ancak zamanla bu yapı ve kavramlar feminist kuramlar içerisinde sorgulanmaya başlanmış ve çeşitli eleştirilere uğramıştır. Feminist kuramlar, örgütsel kuramlar içerisinde uzun yıllar boyunca ihmal edilen, örgütlerde toplumsal cinsiyet, güç ilişkileri ve cinsiyet eşitsizliği konuları üzerine yoğunlaşarak, örgüt kuramı yazınına farklı bir boyut kazandırmışlardır. Bu bağlamda çalışmanın temel amacı, feminist kuramların incelenmesi ve örgüt kuramına yaptıkları katkıların değerlendirilmesidir.
\end{abstract}

Anahtar Kelimeler: Feminizm, Feminist Kuramlar, Örgüt Kuramları, Toplumsal Cinsiyet

\section{Abstract}

Approaches to women, gender, and gender relations have been ignored for a long time in organizational studies. On the basis of this situation lies in the dominance of male-dominated social structure in the organizational field as in every field. As a matter of fact, the roles imposed by women on the society in the historical process made it diffucult for women to participate in the working life has led to the involvement of men to a great extent in the formation and management of organizations. Therefore, in such a structure, organizational studies have generally been shaped from a male point of view and focused more on concepts such as hierarchy, power and authority distribution. Gender-related issues, on the other hand, were generally handled based on statistical data. However, in process of time, these structures and concepts have been questioned within feminist theories and have been subjected to various criticisms. Feminist theories have brought a different dimension to organizational theory literature by focusing on the issues of gender, power relations and gender inequality in organizations, which have been neglected for many years in organizational theories. In this context, the main purpose of the study is to examine feminist theories and evaluate their contributions to organizational theory.

Keywords: Feminism, Feminist Theories, Organization Theories, Gender

Çelik, D. (2020). “Feminist Örgüt Kuramları”, Journal of Academic Value Studies, 6(3) 231-243 (http://dx.doi.org/10.29228/javs.45673).

\footnotetext{
*E-mail address: dcelik060@yahoo.com
} 


\section{Giriş}

Feminist düşünce, ilk ortaya çıktığı andan günümüze kadar uzanan süreç içerisinde tepkisel bir hareket olarak gelişmiştir. Kadınların ezilmişliğinin, baskı alında kalışının ve erkeklerle eşit fırsatlara sahip olmayışının sorgulanması ve bu doğrultuda ilk olarak siyasal hakların talebiyle yükselen kadın sesi, zamanla birçok alanda kadınların erkeklerle eşit firsatlara sahip olması için mücadele etmiştir. 1980'li yıllara kadar genellikle siyasal, sosyal ve ekonomik alanlarda eşitliğin elde edilmesine yönelik düşünceler etrafında şekillenen feminist yaklaşımlar, bu dönemden itibaren post-modern düşüncenin toplumsal cinsiyet konusunu söylemsel düzeyde ele almasıyla yeni bir ivme kazanmıştır.

Feminist düşüncede ortaya çıkan farklı yaklaşımlar diğer birçok disiplinde olduğu gibi, örgütsel çalışmalarda da kendisini hissettirmiştir. Örneğin, liberal feministler "yönetimde kadınlar" araştırmaları ile örgütlerde kadınların neden yönetici pozisyonda yer alamadıklarını ve karşılaşıtıları engelleri araştırırken, radikal feministler alternatif örgüt yapıları, psikanalitik feministler kadınların farklı özelliklerinin örgütlerdeki önemi ve sosyalist feministler de örgütlerde cinsiyet yapılanmaları ve mesleki cinsiyet ayrımı gibi konular üzerinde araştırmalar yürütmüşlerdir. Post-modern feministler ise daha farklı olarak örgütlerde toplumsal cinsiyetin söylemsel boyutunu değerlendirirken, post-kolonyal feministler de "kalkınmada kadınlar” araştırmaları ile örgütsel çalışmalara önemli katkılar sağlamışlardır.

Buradan hareketle, bu çalışmada ilk olarak feminizm kavramının anlamı ve kısa tarihçesinin ele alınmasının ardından, farklı feminist kuramlar ve bu kuramların örgüt çalışmalarına katkıları değerlendirilecektir.

\section{Feminizm Kavramı}

Feminizm, temelde kadın ve erkek arasındaki güç ilişkilerinin değişmesini hedefleyen ve temel endişesi kadın özgürlüğ̈̈ne dayanan siyasal bir harekettir.

Feminizm kelimesinin kökeni Fransızca kadın anlamına gelen “femina” sözcüğünden türemiştir (Pandey, 2002: 87). Kavram zamanla kadın hakları hareketi ve cinsiyet eşitliği kuramı olarak benimsenerek 1890’lardaki kadıncılık (womanism) kavramının yerini almışıı (Kent, 2004: 275; Alptekin, 2011: 35). Feminizm kavramının evrensel bir tanımın yapılması oldukça zordur. Çünkü kadın özgürlük hareketinin yıllar boyunca çeşitli anlamlar geliştirmesi ve kadınlar için mücadele edenlerin düşüncelerindeki farklılık, kavramın tek bir açıdan tanımlanmasını zorlaştırmaktadır. Fakat genel bir ifadeyle feminizm, biryandan kadınlara erkeklerle eşit haklar tanınmasını, bir yandan da kadınların erkeklerden farklı olduğunun dikkate alınması gerektiğini savunan ve temeli kadın özgürlüğüne dayanan sosyal, siyasal ve hukuki bir akım, olarak tanımlanabilir (Güriz, 1997: 2).

Feminizmle ilgili ilk yaklaşımlar 17. yüzyılda ortaya çıkmış ve 1960 'lı yıllardan itibaren küresel bir nitelik kazanmıştır (Singh, 1995: 59). 17. yüzyılda İngiltere'de Feodalizmin yıkılması ve kapitalizmin gelişmesiyle birlikte kendini toplumdan dışlanmış bir sosyolojik grup olarak hisseden orta sınıf kadınlarının talepleriyle ortaya çıkan feminizm hareketi, 18. yüzyıla gelindiğinde teorik bir anlam kazanmışıtır (İşler, 2004: 14). Mary Wollstonecraft'ın 1792'de yayımlanan ve feminist kuram tarihindeki ilk önemli çalışma olan "A Vindication of the Rights of Woman” (Kadın Haklarının Savunusu) adlı eseri, feminist düşünce için başat eser olmuştur (Donovan, 2009: 15). Wollstonecraft'ın çalışmasında, kadının özel alana hapsolmaması ve eğitimde, iş dünyasında ve siyasette erkeklerle eşit fırsatlara sahip olmasına vurgu yapılmaktadır.

18. yüzyılın sonlarına doğru giderek güçlenen feminizm hareketi, 19. Yüzyılın başlarından itibaren kadınların haklarını elde edebilme amacıyla bir araya gelmeleri sonucunda çeşitli kadın örgütlerinin (Uluslararası Kadın Konseyi, Uluslararası Kadınlara Oy Hak Birliği vb.) ortaya çıkmasıyla daha etkili bir harekete dönüşmeye başlamıştır. Bu dönemin ikinci yarısında kadınlara oy hakkının sağlanması yönünde ABD'de ve İngiltere'de başlayan kadın özgürlüğü hareketi, I. Dünya Savaşı'nın ardından 21 ülkede kadınlara oy hakkının tanınmasıyla siyasi anlamda önemli bir zafer kazanmıştır. Yine bu dönemde "eşit işe, eşit ücret ilkesi” feminist kadınların baskın talepleri neticesinde Milletler Cemiyeti Sözleşmesi' nde yer almıştır (İşler, 2004: 15-16).

Kadın özgürlüğ̈̈ hareketi I. Dünya Savaşı'ndan sonra daha da gelişerek 1960'lı yıllardan itibaren farklı bir boyut kazanmıştır. Bu dönem ikinci dalga feminizm hareketinin başladığı yıllardır. İkinci dalga feminizm gündemini, özel alan ve özel alandaki eşitsizlikler bağlamında biçimlendirmiştir. Bu dönemde özel alanın siyasetten ayrı olmadığı, yani özelin (kişiselin) de siyasi olduğuna vurgu yapılmıştır. İkinci dalga feminist hareketi en fazla etkileyen iki eser Simone de Beauvoir’ in 
“İkinci Cins” (Le Deuxieme Sexe) ve Betty Friedan’ın “Kadınlı̆̆ın Gizemi” (The Feminine Mystique) adlı yapıtlarıdır. Bu iki eserde de genel olarak kadın olmanın erkek egemen bir toplumda ne anlama geldiği ve kadınlık halleri sorgulanmaktadır (Ayata, 2011: 67-68). Bu dönemde gündeme gelen belli başlı konular, cinsellik, aile, işyeri, doğum kontrolü ve kürtaj, üreme/ürememe hakları ve cinsel eşitliktir. Bu konular, siyasal olmanın ötesinde kadın hareketine daha genel ve radikal bir dönüşüm boyutu kazandırmaktadır.

Son olarak, 1980’li yılların sonlarından başlayıp günümüze kadar uzanan ve uluslararası alanda meydana gelen değişikliklerle birlikte bireylerin kendilerini, sahip oldukları yurttaşlıkların yanı sıra, ırksal, etniksel, dinsel ve cinsel kimlikleriyle de ifade etmeye başladıkları bu dönem, üçüncü dalga feminizm olarak adlandırılmaktadır. İkinci dalga feminizme bir tepki olarak ortaya çıan üçüncü dalga feminizm dönemindeki tartışmalar daha çok kadın hareketlerinin daha geniş bir tabana yayılarak, kadının güçlendirilmesi gibi konular etrafında şekillenmiştir (Tür ve Koyuncu, 2010: 6-7).

\section{Feminist Kuramlar ve Örgüt Kuramına Katkıları}

1980’li yıllara kadar örgüt çalışmaları ve feminist kuramlar kendine özgün alanları nedeniyle ayrılmışlardır. Örgüt literatürüne, erkek yöneticilerin sorunlarını çözmek için erkek akademisyenler hakimken, feminist çalışmalar daha çok ataerkil ilişkilerin doğası ve kadınlarla ilgili konulara yönelmiştir. Kadının ikincilliğine ve cinsiyet eşitsizliğe yönelik çalışmaların uzun bir geçmişi olmasına rağmen, örgütlerde cinsiyet ayrımı ve diğer toplumsal cinsiyet eşitsizliklerine ilişkin teori ve araştırmaların oldukça yeni olduğu söylenebilir (Irefin vd., 2012: 9).

Çeşitli düşünce akımlarından etkilenerek ortaya çıkan ve vurguladıkları alanlar ve yoğunlaştıkları konular itibariyle çeşitli farklılıklar gösteren çok sayıda feminist kuram bulunmasına karşılık, bu çalışmada bu kuramlar arasından; liberal feminist kuram, radikal feminist kuram, psikanalitik feminist kuram, Marksist feminist kuram, sosyalist feminist kuram, post-yapısalcı feminist kuram ve post-kolonyal feminist kuram ele alınarak, örgüt çalışmalarına yaptıkları katkılar üzerinde durulmaktadır.

\subsection{Liberal Feminist Kuram}

Liberal feminizm, kadın ve erkek arasındaki eşitliğe vurgu yapan ilk feminist kuramdır. Bütün feminist kuramlar bu bakış açısının temelinde adil ve eşit bir toplumun oluşması ve tam bir kadın-erkek eşitliğinin sağlanması için engellerin ortadan kaldırılmasını amaçlamışlardır (Mills vd., 2010: 525).

Liberal feminist kuramın kökleri 17. ve 18. yüzylllardaki liberal siyasal düşüncenin gelişimine dayanmakta ve günümüze kadar uzanmaktadır (Calas ve Smircich, 1996: 219). Bireylerin kendi yeteneklerini geliştirme konusunda özgür olması gerektiğini kabul eden klasik liberal düşünceden temellenen liberal feminizm, kadın ve erkekler arasındaki cinsiyet farklılıklarının nasıl oluştuğuna odaklanmıştır (Demirbilek, 2007: 18-19).

Erken liberal kuramcılar hayatın önemli işlerinin kamusal alanda erkekler tarafından yapılırken, kadının özel alana hapsedilmesine karşı çıkaralar. Kadınların da erkekler gibi saygın mesleklere girebilmelerini ve her alanda erkeklerle eşit firsatlara sahip olmaları gerektiğini savunurlar (Ecevit, 2011: 13; Calas ve Smircich, 1996: 222).

1960 ’lı yıllara kadar liberal feminist düşünce kadın-erkek eşitliğine vurgu yaparken, sonrasında eşitliğin ötesinde ve hatta eşitlik yerine kadını erkek egemen toplumdan kurtarmayı amaçlamıştır. Bununla birlikte kadınların her ne kadar özel alanda erkek egemenliğinden bir şekilde kendilerini kurtarabilseler de piyasada eşit olarak rekabet edemeyeceklerini ve iş hayatında erkeklerin baskısının devam edeceğini de belirtmişlerdir. Kadının iş hayatındaki başarısızlığının en önemli nedeni ise, çocuk bakımı ve ev işleri gibi sorumlulukların ağırlığı olarak görülmektedir. Bu nedenle kadına çocuk sahibi olmama ve kürtaj hakkı gibi yasal hakların verilmesi gerektiği savunulmuştur (Altınbaş, 2010: 26-27).

1960 'lı yıllardan itibaren liberal feminist yaklaşımlar cinsiyet ayrımcılığına ve örgütsel ve toplumsal alanda bu ayrımın ortadan kaldırılması gerektiğine odaklanmışıı. İş hayatında kadının erkek egemenliğine maruz kalmasının ve yüksek mevkilere ulaşamamasının nedeni olarak da örgütlerdeki cam tavan (glass ceiling) varlığına işaret edilmiştir (Mills vd., 2010: 526). Cam tavan kavramıla, örgütsel önyargılar ve kalıplar tarafından yaratılan ve kadınların üst düzey pozisyonlara ulaşmasını engelleyen görünmez ve yapay engeller ifade edilmektedir (Wirth, 2001: 1). Cam tavan engeli, kadınların örgütsel alanda cinsiyet ayrımcılığı ile karşı karşıya kalmasına ve erkeklere oranla daha düşük pozisyonlarda istihdam edilmesine neden 
olmaktadır. Liberal feministler örgütsel alandaki bu anlayışın değişmesini ve cinsiyet ayrımı gözetmeyen (gender-neutral) bir örgütsel alanın oluşturulması gerektiğini savunmaktadırlar.

Yönetim ve örgüt literatüründe toplumsal cinsiyete ilişkin çalısmalar özellikle 1960 'lı yıllardan sonra liberal siyasal düşüncenin varsayımlarıyla bağlantılı olarak "yönetimde kadınlar" (women in management) kategorisi altında gelişmiştir (Calas ve Smircich, 1996: 223). Yönetimde kadın araştırmaları özellikle "eğer kadın yönetici olursa” sorusuna yanıt aramıştır. $\mathrm{Bu}$ araştırmaların zaman içerisinde artmasıyla birlikte sorular, örgütlerde kadın ve erkekler arasındaki davranışsal, zihinsel ve duygusal açıdan ne tür farklılıkların olduğuna yönelmiştir (Hartl, 2002: 15).

Özetle, liberal feminizm fırsat eşitliği, pozitif ayrımcılık ve cinsiyet ayrımcllı̆̆ konularını ele almıştır. Liberal feministlerin öncülügünde yönetimde kadınlar araştırmaları ile daha çok örgütlerde süregelen cinsiyet ayrımcllı̆ına (cam tavan engeli) vurgu yapan konular ele alınarak, bu durumun nedenleri sorgulanmışır. Liberal feministler böylece örgütsel çalışmalarda uzun yıllar boyunca ihmal edilen toplumsal cinsiyet ve kadın-erkek eşitsizliklerinin gündeme getirilmesine öncülük etmişlerdir.

\subsection{Radikal Feminist Kuram}

Radikal feminizmin temel düşüncesi, erkeklerin, kadınların sömürülmesinden yararlandıkları ve bu sömürülmenin de asıl sorumlusunun erkekler olduğu anlayışına dayanmaktadır (Giddens, 2006: 471). 1960'lı yıllarda eşit haklar arayışından farklı olarak kadının özgürleşmesinden söz eden radikal feministler, kadının ikincilliğinin nedenini ataerkil toplumsal yapının bir sonucu olarak görmektedirler (Altun, 2008: 70).

Radikal feministler, kadın ve erkek arasındaki hiyerarşik yapının ataerkil toplumsal yapının yanı sıra, kadın ve erkek arasındaki biyolojik farklılıklardan kaynaklandığına vurgu yapmışlardır (Jaggar, 1983: 88). Onlara göre kadınlar üzerindeki baskının asıl nedeni, kadının özel alandaki rolü ve cinsellik, üreme kapasitesi, annelik, aile hayatı ve kültür gibi kadınların toplumsal cinsiyet egemenliğine dayalı rollerinden kaynaklanmaktadır (Abramovitz, 1996: 23). Kadınlar cinsellik ve çocuk doğurma/doğurmama gibi haklara kendi iradeleriyle karar verebilmelidirler. Bu yüzden istenmeyen gebelikleri önleme ve kürtaj gibi kimi haklar kadınların kendi bedenleri üzerindeki özgürlügünü elde etmelerine yardımcı olabilecektir (Ecevit, 2011: 14-15).

Liberal feministler aile içerisinde kadının ikincilliğini kabul ederken, radikal feministler aile içerisinde kadının sömürülmesine vurgu yaparak, aile kurumunu reddetmekte ve sosyal yapı ve normların değişmesinin gerekliliğine odaklanmaktadırlar. Onlara göre aile ve toplum erkeklere daha fazla güç sağlamak için düzenlenen yapılardır ve bu yapılar kadınların sağlıklı bir şekilde görevlerini yapmaları açısından negatif sonuçlara yol açmaktadır (Voorhis, 2008: 268).

Radikal feminizm, kadını merkeze alan bir yaklaşımdır. Birçok bilimsel teori ve veriler sadece kadını dışlamasından dolayı değil, aynı zamanda kadın merkezli olmadığı için radikal feministler tarafından reddedilmiştir (Irefin vd., 2012: 1011). Bu bağlamda radikal feministler kadınları merkeze alan, kadın kültürünü destekleyici ve erkeklerin ihlal edemeyecekleri "kadın alanı" (womanspace) oluşturmaya çalışmışlardır (Shands, 1999: 61). Kadın alanları, kadınların ihtiyaçlarını giderecek alternatif kurumların ve örgütlerin yaratılması demektir (Calas ve Smircich, 1996: 227). Kadın alanları, kadınlar için daha fazla özgürlük talebiyle, onların periyodik olarak erkeklerin etkisinden kaçabilecekleri, kendi cinsleriyle birlikte olabilecekleri, öz-imajlarını geliştirebilecekleri ve kendi kültürlerini (kadın kültürünü) oluşturabilecekleri bir yapıyı temsil etmektedir (Becker-Schmidt, 1999: 109).

Radikal feminist gruplar, "kişisel olan siyasaldır" sloganıyla ve evrensel kız kardeşliğine çağrı yaparak kadınların kişisel deneyimlerini, inançlarını ve daha birçok konuyu paylaşabilecekleri bilinç yükseltme grupları oluşturmuşlardır. Kadının özgürlüğünü savunan bu gruplar, hiyerarşik yapılara karşı kollektivist ve lidersiz örgütsel mevki ve yapılar oluşturma eğilimindelerdir (Musil, 2000: 596). Siyasal alanda çok fazla etkili olmayan bu gruplar zamanla çözülmüş olsalar da örgütsel alanda eşitlikçi ve baskın olmayan bir yapı geliştirmeye çalışmışlardır (Calas ve Smircich, 1996: 227).

Kısaca, radikal feministler kadın merkezli örgütsel yapıların oluşturulmasını gündeme getirerek, örgütsel çalışmalarda kadını merkeze alan incelemelerin yapılmasına önemli ölçüde katkıda bulunmuşlardır. 


\subsection{Psikanalitik Feminist Kuram}

Psikanalitik feminist kuram, Freud'un psikoseksüel gelişimde ödipal evreye ilişkin yapmış olduğu deneysel çalışmalarına dayanmaktadır (Madsen, 2000: 94). Freud'un kadın ile erkeğin aile içindeki rollerini saptamaya yönelik deneysel çalışması ve bundan da önemlisi çocuğun toplumsal olarak belirlenmiş yetişkinlik rolüne doğru gelişim sürecini betimlemesi, çağdaş feminist kuram açısından önemli bir temel oluşturmaktadır (Donovan, 2009: 175).

Freud'un çalışması kişinin cinselliği ve onun ruhsal gelişimi üzerinde odaklanmıştır. Freud, cinsiyet ve toplumsal cinsiyetin birbirini takip eden süreçler olduğundan bahsetmekte ve insan ruhunun üçlü bir yapiya sahip olduğunu ve bu yapıların da ego, süperego ve id olarak tanımlanabileceğini belirtmektedir (Nicolson, 1996: 55). İd, kişiliğin biyolojik parçası ve insanın doğuştan sahip olduğu tüm dürtülerin kaynağı; ego, kişiliğin düzenleyici, denge ve uyum sağlayıcı parçası ve son olarak süperego ise çocukluk devresinde, çocuğa ailesi ve toplum tarafından aktarılan geleneksel değerlerin etkileşimi sonucunda gelişen yapıdır (Özdemir vd., 2012: 570).

Öte yandan Freud, kişinin ruhsal-cinsel gelişiminde beş farklı aşamanın olduğundan bahsetmekte ve bu aşamalardan üçüncü evreyi de (phallic stage) ödipal karmaşanın yaşandığı, süperegonun oluştuğu ve aynı zamanda cinsel farklılıkların algılanmaya başlandığı yaklaşık 3-5 yaş arası dönem olarak belirtmektedir (Parrish, 2010: 61). Çocuğun cinsel yasakları öğrenmeye başladığı bu dönemde, başlangıçta hem kız hem de erkek çocuk annesine karşı yoğun bir ilgi beslemektedir. Ancak bu dönemde erkek çocuk annesinin sevgisi konusunda kendisiyle yarışan başka birinin, yani babasının olduğunun farkına varır ve babasını kendisinin rakibi ve düşmanı olarak algılamaya başlar. Babasını öldürme ve onun yerine geçme düşüncesine kapılan erkek çocuk, babasının kendisinden daha güçlü olduğu ve şayet bu arzudan vazgeçmez ise cezalandırılacağı (penisini kaybetme) korkusuyla annesinden vazgeçerek kendisini babasıyla özdeşleştirmeye başlar. Bu süreçte erkek çocuğun babası gibi olabilme ve iktidarı elde etme düşüncesi ise anne sevgisinin yerine geçer (Thurshwell, 2009: 45).

Erkek çocuk ödipal dönemde babasıyla özdeşleşmeye başlarken, kız çocuk bu dönemde karşı cinsin bir penisi olduğunu ve kendisinin bundan yoksun olduğunu fark ettiği an, bu olguyu kötü muamele olarak değerlendirerek, aşağılandığını hisseder. Zamanla bu eksikliğin değişmeyeceğini anlamasıyla, babasına bir çocuk doğurmayı isteyerek penis yoksunluğunu telafi etme çabasına girer. Freud bu durumu "penis kıskançlı̆̆ı" olarak nitelendirmekte ve kıskançlı̆̆ın nesnesi de anne olarak görülmektedir. Bu kızların ödipal karmaşasıdır ve Freud, kızların bunun nasıl ötesine geçtiğini açılayamamıştır (Donovan, 2009: 182-184). Bu kapsamda penis erkek çocuk için gelecekteki gücün kaynağı olarak görülürken, kız çocuk için güçten yoksun olma anlamına gelmektedir.

Psikanalitik feminist kuramcılar ilk olarak, Freud'un “anotomi kaderdir” biçimindeki düşüncesini açık bir biçimde biyolojik determinizm olarak nitelendirmekte ve bu düşünceyi ciddi bir biçimde eleştirmektedirler (Donovan, 2009: 192). Onlara göre kadın ve erkeğin psikolojik gelişimindeki farklılıklar ataerkil aile gibi belirli sosyal düzenlemeler tarafından yönlendirilmektedir. Dolayısıyla bu yapının değişmesi beraberinde toplumsal alanda erkek hakimiyetinin gerilemesine de katkı sağlayacaktır (Calas ve Smircich, 1996: 229).

İkinci olarak, psikanalitik feministler Freud'un kadınlardaki penis kıskançlı̆ı kavramını da eleştirmektedirler. Bu kapsamda yapılan kimi tartışmalarda, Freud'un penisi, erkeğin gücünü sembolize eden metaforik bir kavram olarak kullandığı iddia edilse de feministler Freud'un kadını cinsel ve psikolojik açıdan gelişmemiş bir yaklaşımla ele aldığını öne sürmektedirler (Andersen ve Taylor, 2006: 92). Freud'a göre annenin, babanın sahip olduğu özelliklere sahip olamamasını niteleyen penis kıskançlığı, psikanaltik feministler tarafından eleştirilmekte ve kadının cinsel kimliğinin gelişiminde babanın değil, annenin daha etkili olduğu ve annelerin ezilmişlik konumlarına rağmen kızları üzerinde olumlu etki yarattıkları savunulmaktadır (Ecevit, 2011: 20). Diğer yandan psikanalitik feminist kuramcılar, Freud'un kişilik gelişimine yönelik açıklamalarını erkek yanlısı olarak görmekte ve bu düşünme tarzından bir an önce kurtulmanın gerekliliğini de vurgulamaktadırlar.

Örgüt çalışmaları açısından baktığımızda psikoanalitik feminizm, örgüt ve yönetimde kadınların rollerini onların farklı fiziksel gelişimlerinin bir sonucu olarak ele almaktadır. Örneğin, Henning ve Jardim tarafından 1977 yılında kaleme alınan "Yönetici Kadın" (The Manegerial Woman) adlı çalışmada, kadın ve erkeklerin erken toplumsallaşma deneyimlerinin ve ödipal karmaşaya yönelik farklı çözümlemelerinin, yöneticilik davranışlarına yansıdığından bahsedilmektedir. Bu çalışmada 
birçok kadının pasif bir biçimde toplumsallaştığı ve kendilerini bir aktör/özne olarak görmek yerine birer mağdur olarak gördükleri belirtilmektedir (Calas ve Smircich, 1996: 230). Toplumun ataerkil yapısının bir sonucu olarak başarı ve liderlik kadınlar için alakasız kavramlar olarak görülmekte ve bu durum örgütlerde kadının daha aşağı bir konumda yer almasına yol açmaktadır (Irefin vd., 2012: 13).

Örgütsel çalışmalarda feminist psikologların ve psikoanalitiklerin (Dinnerstein, Chorodow, Gilligan vd.) etkisi, kadının farklı biyolojik rollerinin işyerlerinde bir eksiklik değil bir avantaj oluşturduğuna dair yaptıkları vurgulardır (Calas ve Smircich, 1996: 231). Çağdaş toplumlarda kadınların örgütlere önemli katkılar sağlayacağına inanılmaktadır. Kadınların empati kurma ve önsezi gibi kimi özellikleri işyerlerindeki iklimin değişmesine ve işyerlerinde daha az hiyerarşik yapıların oluşturulmasına katkı sağlayacaktır. Kadınlarla ilişkilendirilen bu tür özellikler, örgütlerin insan kaynakları açısından son derece önemlidir (Alvesson ve Billing, 2009: 171). Nitekim örgüt kuramı alanında çalışma yapan çoğu feminist araştırmacı kadının farklı özelliklerinin işyerlerinde bir avantaj olduğunu belirterek, bunun aynı zamanda statükoya meydan okumak için bir yol olduğunu da ileri sürmüşlerdir (Calas ve Smircich, 1996: 231).

\subsection{Marksist Feminist Kuram}

Marksist feminist kuram, kadının ikincilliğinin sınıflı toplumsal yapıdan kaynaklandığını ve kadının baskı alında olmasının nedeninin kapitalizm olduğunu vurgulamaktadır (İşler, 2004: 33). Sorunun kaynağını sınıfsal baskıda gören bu yaklaşım, yönetici sınıfın dayattığı hâkim ideolojiye vurgu yaparak, sınıfsız toplumun kadının özgürleşmesi için vazgeçilmez olduğunu savunmaktadır (Özsöz, 2008: 52-53).

Marksist feminist kuramın temel ilkesi, kadınlarının durumlarının düzelmesi için ekonomik değişikliklerin gerçekleşmesinin bir önkoşul olduğudur. Marksist feministler aileyi, ücretsiz ev işleri sunan ve böylece kapitalist toplumun hizmetine yedek ordu sağlayan bir yapı olarak görmektedir (Aitchison, 2009: 635). Böyle bir yapıda kadınlar, yedek ordular olarak kapitalist sistemin yeni üretim kollarının içerisine çekilebilecek işgücü potansiyelini oluşturmaktadıllar (Irefin vd., 2012: 14). Kadınların ücretli emek alanından dışlanmaları ve çocuk dünyaya getirme, çocuk yetiştirme gibi faaliyetleri her ne kadar erkeğin yararına olsa da bundan asıl yarar sağlayan sermaye ve kapitalizmdir (Ecevit, 2011: 16).

Kısaca Marksist feminist kuram, genel olarak ataerkil ve kapitalist örgüt yapısında büyük çaplı değişimler gerçekleşmeden, cinsiyet ilişkilerindeki durumun devam edeceğini iddia etmektedir. Bu açıdan bakıldığında Marksist feminist kuramın örgütsel çalışmalarda çok fazla temsil edilmediği, ancak geleneksel Marksist feminizmin, yerini sosyalist feminist yaklaşımlara bırakarak örgütsel çalışmalara bu noktada önemli katkılar sağladığı söylenebilir (Calas ve Smircich, 1996: 232).

\subsection{Sosyalist Feminist Kuram}

Sosyalist feminist düşünce, Marksist, radikal ve psikanalitik feminist düşünce okullarının birleşmesinden oluşmaktadır (Weisberg, 1996: 13).

Marksist feministler kapitalizm ile iş yerinin evden nasıl ayrıldığını ve evde yapılan faaliyetlerin nasıl önemsizleştirildiğini açıklayabilmişti ancak kapitalizmin neden kamusal alanı erkeklerle, özel alanı ise kadınlarla ilişkilendirdiğini tam olarak açıklayamamıştı. Yine radikal feministler kadına yönelik baskının maddi temellerini belirlemekle birlikte, ataerkilliği evrensel bir olgu olarak görmekteydi. Öte yandan psikanalitik feminist kuram ise kadınların ezilmişliğinin nedenini onların ruhsal yapılarına bağlamaktaydı (Ecevit, 2011: 16-17).

Sosyal feministler de radikal feministler gibi üreme ve kadına yönelik şiddet gibi beden ve cinsellikle ilgili konuları ele almakta ancak bu konuları ataerkillik ve ekonomik konularla bağlantılı olarak değerlendirmektedirler (McLaren, 2002: 10). Sosyalist feministler bu bağlamda bir yandan Marksist kuramın ekonomiye ilişkin açılamalarını, biryandan da radikal ve psikanalitik feminist kuramların cinsellikle ilgili açıklamalarını birlikte ele alarak yeni bir yaklaşım geliştirmişlerdir. Sosyalist feministlerin geliştirdikleri bu yaklaşım "ikili sistemler kuramı" (dual systems theory) olarak adlandırılmakta ve literatürde kimi zaman bu kavram sosyalist feminist kuramın yerine de kullanılmaktadır.

İkili sistemler kuramı, toplumda biri ekonomik sistem ve bir diğeri toplumsal cinsiyet sistemi olmak üzere faaliyet gösteren iki farklı sistemin olduğunu savunmaktadır. Bu ikili sistemler içerisinde kapitalizm, mevcut ataerkil sistem üzerinde gittikçe büyümektedir (Colgan ve Ledwith, 1996: 9). Sosyalist feministlere göre ataerkillik kapitalizmden önce var olmuştur 
ve post-kapitalist toplumlarda da varlığını devam ettirmektedir. Mevcut sistemde güç ilişkileri, ataerkilliğin ve kapitalizmin diyalektik ilişkisinden ve karşılıklı olarak sistemi güçlendiren birlikteliğinden kaynaklanmaktadır (Einstein, 2004: 225-226). Bu kapsamda kapitalizm, tarihsel süreçte üretim tarzından kaynaklanan bir materyal iken, ataerkillik ya bir materyal ya da ideolojik bir yapıdır (Calas ve Smircich, 1996: 232). İkili sistemler kuramı içerisinde kapitalizmle ilgili açıklamalar materyale dayandırılırken, ataerkilliğe ilişkin iki farklı yaklaşım ortaya çıkmaktadır:

Bunlardan ilki Julite Mitchell'in görüşlerine dayanmaktadır. Mitchell, kadının konumunun üretimdeki ve yeniden üretimdeki rolü (cinsellik ve çocukların toplumsallaştırılması) tarafından belirlendiğini ileri sürmekte ve kadının ezilmesinin onun ruhsal deneyiminde ekonomik yapıdaki bir dönüşüme (Marksizmden sosyalizme geçiş) eşdeğer bir devrim olmadıkça devam edeceğini ve bu yüzden kapitalizmin bir materyal, ancak ataerkilliğin bir ideoloji olduğunu belirtmektedir. Ataerkillikle mücadele etmek için de psikanalitik görüşlerden yararlanılması gerektiğini öne sürmektedir (Calas ve Smircich, 1996: 232; Ecevit, 2011: 17).

İkili sistemler kuramındaki diğer yaklaşım ise Heidi Hartman'ın görüşlerine dayanmaktadır. Hartman, Marx’ın tarihsel materyalizmini ele alarak bir değerlendirme yapmaktadır. Ona göre Marx, yeniden üretim ilişkileri ile ataerkillik arasındaki ilişkiye önem vermemektedir. Hartman’a göre ataerkillik, kadınlar üzerinde egemenlik oluşturan erkekler arasındaki sosyal ilişkiler bütünüdür ve sınıf sistemi de ataerkillik gibi materyal temele dayanmaktadır. Bu temel, erkekler tarafından kadınların cinselliği üzerindeki hakimiyetine ve onların ekonomik kaynaklara ulaşmadaki kontrolüne dayanmaktadır (Mccann ve Kim, 2003: 156).

Bu iki yaklaşımın ardından Slyvia Walby de kapitalist bir toplumda ataerkil ilişkilerin temel alanlarını; ev içi işler, ücretli emek, devlet, din, cinsellik gibi kavramlarla tanımlamıştır. Walby'e göre, ev içi işlerin yapılmasındaki sosyal ilişkiler ataerkil üretim biçimini oluştur ve bu yapı toplumsal cinsiyet ilişkilerinin belirlenmesinde oldukça etkilidir (Ecevit, 2011: 18).

Sosyalist feministler örgüt çalışmalarında diğer feminist gruplardan farklı araştırmalar yapmışlardır. Onlara göre örgütün yer aldığı kamusal alan, aile içi ilişkilerin yer aldığı özel alandan ayrı değildir, çünkü örgütler ve aileler içerisindeki ilişkiler karşılıklı olarak birbirlerine bağımlıdır. Bunun anlamı, eğer erkek ataerkil ilişkilerin bir sonucu olarak eşi üzerinde baskınsa, kapitalist erkek de kapitalizmin bir sonucu olarak iş̧̧i kadın üzerinde egemen olmaktadır (Irefin vd., 2012: 16).

Sosyalist feminist çalışmalarda cinsiyete dayalı iş bölümü, örgütlerde cinsiyet yapılanması ve mesleki cinsiyet ayrımı konuları önemli bir başlangıç noktasıdır (Calas vd., 2007: 92). Sosyalist feministler bu konuları ele alarak örnek vaka incelemeleri yapmışlardır. Burada birçok farklı grup (sosyologlar, örgütsel kültür araştırmacıları vb.) tarafından yapılan deneysel araştırmalar, toplumsal cinsiyete dayalı varsayımların sosyal beklentiler altında nasıl gizlendiğini ve aynı zamanda örgütsel kurallar ve uygulamalar ile ilişkili olduğunu göstermiş̧ir (Calas ve Smircich, 1996: 234).

Kısaca sosyalist feministler toplumsal cinsiyet, ırk, sınıf ve cinsellik gibi birçok konuyu ele almışlar fakat bu konuların örgütsel araştırma çerçevesini geliştirmeleri oldukça zor olmuştur. Acker bu problemi ele alarak, toplumsal cinsiyetçi ve ırksallaştırılmış süreçlerin bir sınıf olarak yeniden kavramsallaştırılması için, ücretsiz emek, dağıtım, üretim ve yeniden üretimi içeren bir ekonomide somut uygulamaların incelenmesi gerektiğini savunmuştur (Holvino, 2010: 258).

\subsection{Post-yapisalc1 / Post-modern Feminist Kuram}

Post-yapısalcılık, 1980’li yılların sonlarında sosyal bilimlerde oldukça etkili olan ve yapısalcılığa karşı ciddi eleştirilerde bulunan disiplinlerarası entelektüel bir harekettir. Bu hareket, birçok alanda olduğu gibi, feminist düşüncenin de farklı bir boyut kazanmasında oldukça etkili olmuştur. Post-yapısalcılık nesnel bilginin olasılığına ve soyutluğu nedeniyle üst anlatılara eleştirel bir tutum sergilerken, aynı tutum ile post-yapısalcı feminist kuram da genel olarak modernitedeki "dişil” yapıyı sorgulamaktadır (Gherardi, 2005: 217).

Post-yapısalcı düşüncenin şekillenmesinde felsefeci Jacques Derrida, tarihçi Michel Foucault ve psikoanalist Jacques Lacan'ın çalışmalarının önemli katkıları olmuştur. Fransız post-yapısalcı feministlerden bazıları özellikle de Julia Kresteva, Luce Irigaray ve Helene Cixoux bu düşünürlerin çalışmalarından yola çıkarak feminist eleştirilerde bulunmuşlardır (JontePace, 2002: 124). Anglo-Amerikan post-yapısalcı feminist kuramcılar büyük ölçüde Foucault'un bilgi-güç argümanlarıyla ilişkili olarak çalışmalarda bulunurken, bir grup post-modern feminist kuramcı da Lyotard'ın üst anlatılara ilişkin post 
modern şüpheciliğiyle ilgili çalışmalarından yararlanarak çeşitli yaklaşımlar ortaya koymuşlardır (Calas ve Smircich, 1996: 235).

Post-yapısalcı yaklaşım Ferdinand de Saussure'nin yapısalcı dilbiliminden hareketle ve eleştirel bir biçimde temsili bir yapı olarak dilin değişkenliğini açıklamaya çalışır. Post-yapısalcılara göre dil hem her yöne çekilebilen hem de belirsiz (muğlak) bir şeydir. O halde şimdiye kadar söylenen bilginin gerçek olma ihtimali de onun temsili dışında ve dilin dışında mevcut olabilmesine bağlıdır (Calas ve Smircich, 1996: 235). Onlara göre, tek bir doğru ve seçkin bir bilgi yoktur; bütün bilgiler özellikle tarihsel ve kültürel belirli söylemlerin bir ürünü olarak ortaya çıkmaktadır. Bu söylemlerin gücü de onların doğru olduğuna dair öne sürülen iddiaların başarılı bir biçimde sunulmasıyla ilişkilidir (Tyler, 2011: 18). Bu noktada post yapısalcılar nesnel bilgiyi imkânsız olarak görmekte ve bilgimizin kaçınılmaz bir biçimde bize sunulan dil tarafından sınırlandığına işaret etmektedirler (Ecevit, 2011: 22). Post-yapısalcılık akımının nesnel bilgiye karşı çıkarak, dilin ve söylemin önemine vurgu yapan önemli düşünürlerinden Derrida’nın "yapı bozumu” kavramı, Foucault’un yapısalcılığa yönelik "söylem analizi”, Lacan'ın "psikanaliz yaklaşımı" ve Lyotard'ın "dil oyunları" yaklaşımı, post yapısalcı feministlerin toplumsal cinsiyete ilişkin açıklamalarının şekillenmesinde oldukça belirleyici olmuştur. Post-yapısalcı akıma etki yapan bu düşünürler farklı analiz stratejileri kullansalar da bu analizlerin arasında açık bir biçimde benzer özelliklerin olduğu görülmektedir. Hepsinin odağında; metinlerin yeniden okunması, metin ve anlamların yapı bozumuna uğratılması, birden çok anlam oluşumundaki gizli süreçlerin açığa çıkarılarak alternatif anlamların yeniden kurulması gibi stratejiler yer almaktadır (Bendl, 2000: 384).

Post-yapısalcı feminist kuramcılar, post-yapısalcı düşüncenin çeşitli argümanlarını kullanarak, diğer feminist yaklaşımlardan farklı bir duruş sergilemişlerdir. Liberal, Marksist, sosyalist, psikanalitik ve buna benzer birçok feminist kuram genellikle kadının nasıl ve niçin baskı altında kaldığına ve bu durumun nasıl düzeltileceğine odaklanırken; post-yapısalcılık özellikle cinsiyetten (biyolojik) bağımsız, teorik olarak toplumsal cinsiyetin dikkate alınmasını sağlamıştır (Calas ve Smircich, 1999; 659-660).

Post-yapısalcı feministlere göre toplumsal cinsiyet bir toplumda, toplumsal olarak inşa edilen bir olgudur. Toplumsal cinsiyet kimliğinin gelişimi, sosyal yapının içerisinde ve aynı zamanda toplumsal kimliğin sosyal kavramlarıyla bağlantılı olarak yerleşmiştir. Kadınlar, toplumsal cinsiyet gelişimlerini etkileyen cinsellik, ırk, sınıf, din gibi kategorilerle ilişkili birçok kimliğe sahiptirler (Harris ve Lester, 2009: 105). Dolayısılla bu durum toplumda kadının birden fazla kategoriden etkilendiğini ve bu bağlamda da kadın sorununa yönelik tek bir yaklaşımın olamayacağını göstermektedir (İşler, 2004: 36).

Post-yapısalcı feminist kuramcılar aynı zamanda diğer feministlerin “ayrıcalıklı bakış açısını” eleştirmişlerdir. Onlar, kadın ve kadının deneyimleri olarak kavramsallaştırılmış olguların yeniden değerlendirilmesinin gerekliliğini vurgulamışlardır. Onlara göre erkek deneyimlerinden farklı veya ataerkilliğin dı̧̧ında sözde doğal bir kadınlık/kadın deneyimi yoktur. Dahası, kadın veya erkeğin öznellikleri, deneyimleri ve arzuları, daima söylemler ve söylemsel pratikler tarafından oluşmaktadır (Malson, 1998: 37) Kısaca, post-yapısalcı feministler, kadın ve erkeğin birbirinden farklı iki ayrı kategori olarak ele alınmasını reddederek, çoğulculuğa vurgu yapmaktadırlar.

Post-yapısalcı feministlerin ele aldıkları diğer bir konu ise Freud'un psikanalitik yaklaşımına ve Lacan'ın bu kapsamdaki değerlendirmelerine dayanmaktadır. Lacan'a göre cinsel farklılıklar dil içerisinde oluşmaktadır. Çocuk kendisini "ben" olarak tanımlamaya başladığından itibaren, cinsel farklılıkları tanımlamaya başlar. Dilin kullanılmasıyla birlikte çocuk kendini ve diğerini ayırt eder. Post-yapısalcı feminist kuramcı Kristeva Lacan'ın buradaki yaklaşımından yola çıkarak, söz konusu aşamayı semiyotik aşama olarak değerlendirmekte ve babanın otoritesinin tanımlandığı diğer aşamayı ise sembolik evre olarak tanımlamaktadır (Tolan, 2006: 334-335). Bu kapsamda sosyal düzen ve ataerkil yapı aslında sembolik bir yapı olarak görülmektedir.

Yine post-yapısalcı feministler biryandan sosyal gerçekliğin doğasındaki belirsizliği, karmaşıklığı ve kararsızlığı kanıtlamaya çalışırken, bir yandan da toplumsal cinsiyet ve diğer sosyal kategoriler arasındaki kesişimselliği açıklamaya çalışmıstır (Calas ve Smircich, 1996: 37).

Post-yapısalcı feministler için toplumsal cinsiyete bakış açısı, örgütlerde kadınlar ve erkeklere ilişkin olarak değil, onlara dair dilin kullanılmasını ifade eden söylemlerle ilgilidir (Alvesson ve Billing, 2009: 37). Dilbilimsel dönüş, kaygıları kadının bedeninden metin (text) bedenine taşımış ve bu etki kendisini örgütsel çalışmalarda da hissettirmiştir. Bu kapsamda 
artık temel soru, örgüt kuramında toplumsal cinsiyetin nasıl ele alındığı/nasıl yazıldığı ile ilişkilidir (Calas ve Smircich: 1999: 660).

Post-yapısalcıların metinlerin yeniden okunması, onların yapı-bozumuna uğratılması ve alternatif anlamların yeniden kurulmasına ilişkin düşünceleri örgüt kuramını da etkisi altına almıştır. Croizer’in Fransız Bürokrasisine ilişkin çalışmaları, Hawthorne araştırmaları, kurumsal teori, bağlılık kavramı, karar verme süreçlerinde davranışsal yaklaşım, değişim mühendisliği ve Maslow'un motivasyon teorisi, toplumsal cinsiyet çalışmaları açısından ele alınarak yapı-bozumuna uğratılmışlardır (Bendl, 2000: 384).

Son olarak örgütsel çalışmalar açısından post-yapısalcıların bir diğer katkısı da örgütlerdeki güç ilişkilerine dair yaptıkları açıklamalara dayanmaktadır. Post-yapısalcılar, örgütlerdeki eşitsiz güç ilişkilerinin üretilmesinde ve yeniden üretilmesinde söylemlere, kurallara ve uygulamalara dikkat çekmişlerdir. Örgütlerde "sembolik" ve "söylem" kavramlarını gündeme getirerek, kadının kaynaklara ulaşmadaki gücünün bir sorun olmadığını ve bunun gücün kendi yapısının dilinde gizli olduğunu ifade etmişlerdir (Holvino, 2007: 369-370).

\section{7. Üçüncü Dünya/Post-kolonyal Feminist Kuram}

Post-kolonyal feminizm, 1980 ’li yıllarda post-modern düşünce yapısı içerisinde gelişen ve kaynağını post-kolonyal kuramlardan alan eleştirel bir yaklaşımdır.

Post-kolonyal kuramcılar Batı dünyasının “öteki” olarak nitelendirdiği üçüncü dünya kadınlarının sorunlarını gündeme getirebilmek için ortaya çıkmıştır. Üçüncü feminist dalganın başlangıcı olarak kabul edilen Post-kolonyal feminist düşünce, Batılı feminist düşüncenin toplumsal cinsiyet ile ilgili evrenselleştirici eğilimlerine karşı çımaktadır (Mills, 1998: 98). Batılı feministler, kendi siyasi projelerini evrensel olarak görmekteydi ve onlara göre dünya çapında bütün kadınlar baskının aynı evrensel formlarına maruz kalmaktaydı. Ancak kadınlar arasındaki milliyet, ırk, sınıf, bölge, dil, din ve cinsel yönelime dayalı farklılıklar, batılı feministlerin kabul ettiklerinden veya varsaydıklarından farklı olarak uluslararasında ve uluslar içerisinde daha çok bölünmelerin yaşandığını kanıtlamıştır (McEwan, 2001: 96). Post-kolonyal feministlere göre diğer feminist gruplar tarafından yapılan kadın çalışmaları ise daha çok beyaz, orta sınıf ve heteroseksüel kadınların sorunlarını temsil eden çalışmalardır (Calas ve Smircich: 1996: 238; Nzenza, 1997: 222; Narayan, 2000: 80).

Post-kolonyal feministler iki önemli projeyi gerçekleştirmek için çalışmışlardır: Bunlardan ilki, egemen Batılı feminizmin iç kritiğini yapmak ve ikincisi de coğrafi, tarihsel ve kültürel temellere dayalı bağımsız bir feminist strateji oluşturmaktır. Birinci proje yapı-sökümünü içerirken; ikinci proje inşa etmeyi hedeflemektedir (Mohanty, 1997: 255). Bu açıdan bakıldığında post-kolonyal feministlerin, post-yapısalcılardan etkilendiğini söylemek mümkündür.

Post-kolonyal analistler, Batı merkezli bilgi üretiminin yaygın bir biçimde sömürgeleştirmeden ve emperyalizmin meşrulaştırılmasından oluştuğunu ve Batılıların kendi-modalarının bir biçimi olduğunu ortaya koymaktadırlar (Calas ve Smircich, 1996: 239). Bu noktada Batılı metinlerin yapı-sökümüne uğratılmasına yönelik Spivak tarafından yapılan çalışmalar post-kolonyal feminist düşüncede oldukça önemli bir yere sahiptir. Spivak "Madun konuşabilir mi?" (Can the Subaltern Speak) adlı çalışmasında sömürgeleştirmeyi ve onun ataerkilliğini tartışmakta ve sömürgeleştirenlerin yapmış oldukları baskıların yapı-sökümüne uğratılmadıkça, madunların (ötekilerin) seslerinin sömürgeciler tarafından susturuluşunun devam edeceğini belirtmektedir (Hithcock, 2008: 197).

Mohanty (1991), "Feminizm Siyasetinin ve Üçüncü Dünya Kadınlarının Mücadelelerinin Haritası" (Cartographies of Struggle Third World Women and Politics of Feminism) adlı eserinde, siyahi, beyaz ve diğer üçüncü dünya kadınlarının Avrupa-Amerikan hegemonyasından miras kalan çok farklı hikayelere sahip olduklarını ve bu nedenle üçüncü dünya feministlerinin, post-kolonyal insanların ve diğerlerinin tarihsel mücadelelerine ve spesifik konumlarına dayanarak tarihin yeniden yazılmasını savunduklarını belirtmektedir. Mohanty, üçüncü dünya kadınlarının feminizmle ilgili yapmış oldukları çalışmaların genel olarak şu konulara odaklandığından bahsetmektedir: ırkçılık ve emperyalizm hikayelerinde feminist siyasetin temellenmesi; sosyal ve siyasal marjinallik deneyimlerden yola çıkarak baskıların eşzamanlılıklarının değerlendirilmesi; onların/bizim günlük yaşam ve hayatta kalma mücadelelerinin/mücadelelerimizin sınırlandırılmasında egemen devletin rolü; muhalif kurumların yaratılması ve son olarak üçüncü dünya kadınlarının oluşturdukları örgüt ve toplulukların içerisindeki farklılıklar ve çatışmalardır (Mohanty, 1991: 10). 
Post-kolonyal feministler böylece Batılı feministlerin toplumsal cinsiyete ilişkin yaklaşımlarından yola çıkarak, kadınların ortak deneyimlere sahip oldukları düşüncesini eleştirmişler ve kadınların ezilmesinde sadece erkek ve erkek egemen toplumsal yapının ele alınması yerine farklı koşulların da göz önünde bulundurulması gerektiğini vurgulamışlardır. Örneğin, siyahi kadınların baskı alında tutulmasının tek kaynağının erkekler olduğunu söylemek mümkün değildir; toplumsal cinsiyet baskısında ırk ve sınıfın da oldukça önemli olduğu bir gerçektir (McEwan, 2001: 98).

Birinci Dünya/Üçüncü Dünya ilişkileri, küreselleşme tarafından temsil edilen yeni sömürgeleştirme politikaları çerçevesinde yeni bir boyut kazanmıştır. Melezleştirme gibi kavramlar baskın kültürün asimilasyon biçimlerinden birini oluşturmaktadır. Küreselleşme ve ulusötesileşme gibi örgütsel fenomenlerin okunmasında ise "kalkınmada kadınlar" literatürü Üçüncü Dünya kadınlarının öznelliklerine dair mevcut temsil alanını sorunsallaştırmaktadır (Gherardi, 2005: 218).

Kalkınmada kadınlar araştırmaları 1970’li yılların başlarında ekonomik kalkınma, feminist kuramlar ve kültürel antropolojinin arakesitinde ortaya çıkmıştır. Bu araştırmalar başlangıçta Liberal Feministler tarafından kadının teknolojiye ve gelişmiş kaynaklara ulaşması çerçevesinde belirlenen meselelere odaklanmıştır. Sonrasında ise bu çerçeve dünya çapında kalkınma bağlamında diğer kadınların meselelerine nazaran Birinci Dünya kadınlarının meselelerini daha fazla gündeme getiren kadın konfigürasyonlarının tanımlanması üzerinde bir değişikliğe uğramıştır (Calas ve Smircich, 1996: 240-241).

Örgüt kuramında post-kolonyal kuramlar tamamlayıcı ve aynı zamanda oldukça önemli bir role sahiptir. 1970’lerden itibaren Marksizm ve sınıf-merkezli düşünceler demode olurken ve feminist teori kendisini örgütsel hayatta ve yönetimde önemli ve etkili bir alan olarak oluştururken, post-kolonyal kuram da alternatif bir bakış açısı olarak ortaya çımıştır. Bazı araştırmacılar işyerlerindeki aktivitelerin analizlerinde post-kolonyal kuram kullanmışlardır. Örneğin, Driori (2000) İsrail tekstil endüstrisinde Arap ve Dürzi işçiler ile Yahudi yöneticiler arasındaki ilişkileri açıklamaya çalışmıştır. Daha bunun gibi birçok araştırmacı yönetim ve örgüt çalışmalarında post-kolonyal kuramlardan yararlanmıştır (Styhre, 2007: 160-161).

Holvino (2010) çalışmasında, post-kolonyal feminist kuramcıların sınıf, toplumsal cinsiyet ve ırk arakesitinde yaptıkları çalışmaların örgütlerde üç önemli potansiyel katkısının olduğundan bahsetmektedir: Birincisi, ırk, sınıf ve toplumsal cinsiyet ilişkilerine yönelik post-kolonyal feministlerin çalışmaları, gelişmiş ve gelişmekte olan ülkelerde küreselleşme ve sömürgeleştirmenin kadın ve erkekler üzerindeki etkisinin farklı olduğunu açıklamaya çalışmışırı. Bu yapı kendisini toplumsal alanda olduğu gibi, örgütsel alanda da hissettirmektedir. Örneğin, birçok gelişmiş ülkede göçmen kadınların ucuz işgücü olarak görülmesi ve çok düşük ücretlerle çalıştırılması, ABD’de siyahi kadın ve erkeklerin daha düşük işlerde istihdam edilmesi aslında örgütlerdeki cam tavan engelinin bir başka çeşidi olarak görülebilir. İkincisi, ırk, toplumsal cinsiyet, sınıf ve cinsellik karmaşık ve heterojen pozisyonlar olarak tanımlanmakta ve bu karmaşı pozisyonlar örgütsel değişim için farklı ulusal ve ırksal gruplar arasında yeniden kavramsallaştırılmış koalisyonlar kurulmasına imkan tanımaktadır. Üçüncü olarak, post kolonyal feministlere göre, “ötekilerini” sözde temsil ettiklerini söyleyenlere karşı direnmek oldukça önemlidir. Bu nedenle de örgütlerde sadece mağduriyet ve baskı gibi konular hakkında değil aynı zamanda direniş ve hayatta kalma konuları üzerine de çalışmalar yapmak önem taşımaktadır (Holvino, 2010: 13-14).

Netice itibarıyla kalkınmada kadınlar literatürü, post-kolonyal analizler ve toplumsal cinsiyet arasındaki bağı örgütsel literatüre henüz yeni yeni yerleştiriyor olsa da yakın bir zamanda Batı yayınlarında araştırmacılar tarafından bu konuların daha çok dile getirileceği söylenebilir (Calas ve Smircich, 1996: 242). Bu kapsamda örgütsel çalışmalar açısından birçok kadın araştırmacının Birinci Dünya ve Üçüncü Dünya uygulamalarının arakesitindeki renk (siyahi ve beyaz olarak temsil edilenler) çalışmalarının oldukça önemli olduğu ve post-kolonyallar tarafından ortaya atılan örgütlerde kadın ve (erkeğin) gücü ile ilgili küresel analizlerin daha kapsayıcı bir biçimde ele alınarak genişletilmesi gerektiği belirtilmektedir (Holvino, 2007: 371).

\section{Sonuç}

Örgütsel çalışmalar özellikle son otuz yılı aşkın süredir çeşitli düşüncelerin ve özellikle de feminist kuramların etkisi alıında farklı bir bakış açısı kazanmıştır. Örgütlerde cinsiyete/toplumsal cinsiyete ilişkin konuların ve özellikle kadınların örgütlerde karşı karşıya kaldığı çeşitli problemlerin (cam tavan engeli vb.) gündeme getirilmesinde feminist kuramlar hem uygulama da hem de teoride oldukça etkili olmuştur. 
Kadınların gerek toplumda gerekse örgütlerde ezilmişliğinin, ikinciliğinin ve baskı alında kalmasının nedenlerini farklı ancak genellikle birbirleriyle az çok bağlantılı bir biçimde ele alan feminist kuramcılar, toplumda ve örgütsel alanda kadını baskı altında tutan yapıları eleştirel bir değerlendirmeye tabi tutmuşlardır.

Muhtelif düşünce akımlarından etkilenerek ortaya çıkan çok sayıda feminist kuram olmasına karşılık bu çalışmada, örgütsel çalışmalarla bağlantılı olarak bunlardan yedi tanesi ele alınmış ve bunların her birinin örgütsel alandaki etkileri ve örgüt çalışmalarına katkıları değerlendirilmeye çalışılmışır. Örgütlerde kadın-erkek eşitsizliğinden, ırksal, sınıfsal ve bölgesel anlamda kadınlar arası eşitsizliğe kadar birçok konuyu inceleyen feminist kuramcılar, uzun bir süre erkek egemenliği altında şekillenen örgüt literatürüne farklı bir boyut kazandırarak, klasik örgüt kuramlarının yeniden analiz edilmesini sağlamışlardır.

1980'li yıllara kadar feminist araştırmacılar tarafından yapılan çalışmalar genel olarak kadının neden ve niçin baskı alında kaldığına dair konular üzerinden şekillenirken, 1980’li yılların başlarından itibaren post-modern düşüncenin etkisi alında ele alınan konular kadın ve erkek olarak değil, onlara dair söylemlerle ilişkili olarak değerlendirilmeye başlanmıştır. $\mathrm{Bu}$ değerlendirmeler çeşitli felsefeci, siyaset bilimci ve tarihçi düşünürler tarafından geliştirilen ve nesnel bilginin reddine dayanarak şimdiye kadar yapısal olarak kurgulanan kavramsallaştırmaları çeşitli yöntemlerle (metinlerin yeniden okunması, yapı-sökümüne uğratma vb.) yeniden analiz etmeye odaklanmaktadır.

Sonuç olarak, günümüzde feminist kuramcıların katkılarıyla gelişen toplumsal cinsiyete ilişkin örgüt literatürünün Batı toplumları tarafından- özellikle ABD'de ve Avrupa'da- geliştirildiğini ve bu alanda çeşitli çalışmanın yer aldığı görülmektedir. Bununla birlikte birçok ülkede olduğu gibi ülkemizde de toplumsal cinsiyet konusunda çeşitli çalışmalar yapılmasına karşılık, örgüt kuramı alanında bu konuların oldukça cılız kaldığı ve bu doğrultuda alana ilişkin çalışmaların ülkemizde de geliştirilmesi gerektiği söylenebilir.

\section{Kaynakça}

Abramovitz, M. (1996). Regulating the Lives of Women: Social Welfare Policy from Colonial Times to the Present. South End Press, Cambridge MA.

Altun, H. (2008). "Feminist Kuram Doğrultusunda Bir Okuma/ Sahneleme ve Bir Örnek Çalışma: Denizden Gelen Kadın”, Doktora Tezi, Ankara Üniversitesi Sosyal Bilimler Enstitüsü, Ankara.

Alptekin, D. (2011). Sokaktan Akademiye: Kadın Hareketinin Kurumsallaşma Süreci. Selçuk Üniversitesi Sosyal Bilimler Enstitüsü Dergisi, 26: 33-43.

Alvesson, M. \& Billing D.Y. (2009). Understanding Gender and Organizations. Sage Publications, London.

Andersen, L.M \& Taylor F. H. (2006). Sociology: Understanding a Diverse Society. Thomson Learning Inc, USA.

Ayata, A. (2011). "Siyaset ve Katılım" (Ed. Yıldız Ecevit, Nadide Karkıner), Toplumsal Cinsiyet Sosyolojisi, ss. 64-83, Anadolu Üniversitesi Açıköğretim Fakültesi Yayınları, Eskişehir.

Becker-Schmidt, R. (1999). "Critical Theory as a Critique of Society: Theodor W. Adorno's Significance for a Feminist Sociology” (Ed. Maggie O’Neill), Adorno, Culture and Feminism, pp. 104-118, Sage Publications Inc, London.

Bendl, R. (2000). Gendering Organization Studies: A Guide to Reading Gender Subtexts in Organizational Theories. The Finnish Journal of Business Economics, 3: 373-393.

Calas, M.B. \& Smircich, L. (1996). "From 'The Woman's' Point of View: Feminist Approaches to Organization Studies" (Eds. Stewart R. Clegg, Cynthia Hardy, Walter. R. Nord), pp. 218-258, Handbook of Organization Studies, SAGE Publications, London.

Calas, M.B. \& Smircich, L. (1999). "Past Modernisim? Reflections and Tentative Directions", Academy of Management Review, 24(4): 649-671.

Calas, M.B., Smircich, L. \& Bourne, A.K. (2007). "Knowing Lisa? Feminist Analyses of Gender and Entrepreneurship" (Eds. Diana Bilimoria, Sandy Kristin Piderit), Handbook of Women in Business and Management, pp. 78-108, Edward Elgar Publishing Ltd, UK. 
Colgan, F. \& Ledwith, S. (1996). "Women as Organisational Change Agents" (Eds. Sue Ledwith, Fiona Colgan), Women in Organisations: Challenging Gender Politics, MACMILLAN Business Press Ltd, UK.

Demirbilek, S. (2007). Cinsiyet Ayrımcilığının Sosyolojik Açıdan İncelenmesi. Finans, Politik ve Ekonomik Yorumlar Dergisi, 44(511): 12-27.

Donovan, J. (2009). Feminist Teori: Amerikan Feminizminin Entelektüel Gelenekleri, (Çev. Aksu Bora, Meltem Ağduk Gevrek, Fevziye Sayılan), İletişim Yayınları, İstanbul.

Ecevit, Y. (2011). "Toplumsal Cinsiyet Sosyolojisine Başlangıç" (Ed. Yıldız Ecevit, Nadide Karkıner), Toplumsal Cinsiyet Sosyolojisi, ss. 2-30, Anadolu Üniversitesi Açıöğretim Fakültesi Yayınları, Eskişehir.

Gherardi, S. (2005). "Feminist Theory and Organization Theory: A Dialogue on New Bases" (Eds. Haridimos Tsoukas, Christian Knudsen), The Oxford Handbook of Organization Theory, pp. 210-236, Oxford University Press Inc., Newyork.

Giddens, A. (2006). Sociology. Polity Press, Cambridge/UK.

Gürüz, A. (1997). Feminizm, Postmodernizim ve Hukuk: Bir İnceleme. Ankara Üniversitesi Hukuk Fakültesi Yayınları, Ankara.

Harris, F. \& Lester, J. (2009). "Gender-spesific Approaches to Enhancing Identity Development Among Undergraduate Women and Men" (Eds. Shaun R. Harper, Stephen John Quaye), Student Engagement in Higher Education: Theoritical Perspectives and Practical Approached for Diverse Populations, pp. 99-116, Routledge Publications, Newyork.

Hartl, K. (2002). Expatriate Woman Managers: Gender, Culture and Career. Rainer Hamp Verlag Publications, München.

Hithcock, A.L. (2008). Theory for Classics: A Students Guide, Routledge Publications, USA.

Holvino, E. (2007). "Women and Power: New Perspectives on Old Challanges" (Eds. Barbara Kellerman, Deborah L. Rhode), Women and Leadership: The State of Play and Strategies for Change, pp. 361-382, Jossey Bass Publications, USA.

Holvino, E. (2010). Intersections: The Simultaneity of Race, Gender and Class in Organization Studies. Gender, Work and Organizations, 17(3): 248-277.

Irefin, P.; Ifah, S.S. \& Bwala, H.M. (2012). "Organizational Theories and Analysis: A Feminist Perspective”, International Journal of Advancements in Research and Technology, 1(1): 71-97.

İşler, R. (2004). "İktisatta Feminizm ve Türkiye Ekonomisinde Kadının Rolü”, Yüksek Lisans Tezi, Süleyman Demirel Üniversitesi Sosyal Bilimler Üniversitesi, Isparta.

Jaggar, M.A. (1983). Feminist Politics and Human Nature. Rowman \& Littlefield Publishers Inc, USA.

Jonte-Pace, D. (2002). “The Impact of Women's Studies on the Psychology of Religion: Feminist Critique, Gender Analysis, and the Inclision of Women" (Ed. Arvind Sharma), Metholodogy in Religious Studies: The Interface With Women Studies, pp. 97-146, State University of New York Press, USA.

Kent, S. (2004). "Worlds of Feminism” (Ed. Bonnie G. Smith), Women's History in Global Perspective: Volume I, pp. 275-312, University of Illionois Press, Urbana and Chicago.

Madsen, L.D. (2000). Feminist Theory and Literary Practise. Pluto Press, USA.

Malson, H. (1998). The Thin Woman: Feminism, Post-Structuralism and the Social Psychology of Anorexia Nervosa. Routledge Publications, London and Newyork.

McCann, R.C. \& Kim, K.S. (2003). “Theorizing Intersecting Identities: Introduction” (Eds. Carole R. McCann, SeungKyung Kim), Feminist Theory Reader: Local and Global Perspectives, Routledge Publications, Newyork and London. 
McEwan, C. (2001). Postcolonialism, Feminism and Development: Intersections and Dilemmas. Progress in Development Studies, 1(2): 93-111.

McLaren, A.M. (2002). Feminism, Foucoult and Subjectivity. State University of Newyork Press, Albany.

Mills, J.A., Eurepos, G. \& Wiebe, E. (2010). Encyclopedia of Case Study Research: Volume II. Sage Publications Inc, UK.

Mills, S. (1998). "Post-colonial Feminist Theory" (Eds. Stevi Jackson, Jackie Jones), Contemporary Feminist Theories, pp. 98-112, Edinburgh University Press, Edinburgh.

Mohanty, T.C. (1991). “Cartographies of Struggle Third World Women and Politics of Feminism”, (Eds. Chandra Talpade Mohanty, Ann Russo, Lourdes Torres), Third World Women and the Politics of Feminism, pp. 1-50, Indiana University Press, Bloomington.

Mohanty, T. C. (1997). "Under Western Eyes: Feminist Scholarship and Colonial Discourses" (Eds. Anne McClintock, Aamir Mufti, Ella Shohat), Dangerous Liaisons: Gender, Nation and Postcolonial Perspectives, pp. 255-277, University of Minnesota Press, Minneapolis.

Narayan, U. (2000). "Essence of Culture and a Sense of History: A Feminist Critique of Cultural Essentialism" (Eds. Uma Narayan, Sandra Harding), Decentering the Center: Philosophy for a Multicultural, Postcolonial and Feminist World, pp. 80-100, Indiana University Press, Bloomington.

Nzenza, S. (1997). "Women in Postcolonial Africa" (Ed. Phillip Darby), At the Edge of International Relations: Postcolonialism, Gender and Dependency, pp. 214-235, Pinter, London.

Nicolson, P. (1996). Gender, Power and Organization: A Psychological Perspective. Routledge Publications, London.

Özdemir, O.; Özdemir, G.P., Kadak, T.B. \& Nasıroğlu, S. (2012). Kişilik Gelişimi. Psikiyatride Güncel Yaklaşımlar 4(4): 566-589.

Pandey, K.A. (2002). Feminist Versions and Law. The Banaras Law Journal, 31: 87-104.

Parrish, M. (2010). Social Work Perspectives on Human Behaviour. Open Univesity Press, Maidenhead.

Singh, I. (1995), Feminism: Various Approaches and Its Values. Indian Journal of Theology, 37(1): 58-67.

Styhre, A. (2007). "Post-Colonial Theory" (Eds. Richard Thorpe, Robin Holt), The Sage Dictionary of Qualitative Management Research, SAGE Publications, London.

Tolan, F. (2006). "Feminisms" (Ed. Patricia Waugh), Literaty Theory and Criticism, pp. 319-339, Oxford University Press, Newyork.

Thurshwell, P. (2009). Sigmund Freud. Routledge Publications, London.

Tyler, M. (2011). “Postmodern Feminism and Organization Studies: A Marriage of Inconvenience?” (Eds. Emma L. Jeanes, David Knights, Patricia Yancey Martin), Handbook of Gender, Work and Organization, John Wiley and Sons Ltd Publications.

Tür, Ö. \& Koyuncu, A.Ç. (2010). Feminist Uluslararası İlişkiler Yaklaşımı: Temelleri, Gelişimi, Katkı ve Sorunları. Uluslararası İlişkiler Dergisi, 7(26): 3-24.

Voorhis, V. M. R. (2008). "Feminist Theories and Social Work Practise” (Ed. Roberta R. Greene), Human Behavior Theory \& Social Work Practise, pp. 265-290, Transaction Publishers, New Brunswick.

Weisberg, K.D. (1996). "Pornography: Introduction" (Ed. D.K. Weisberg), Applications of Feminist Legal Theory to Women's Lives: Sex, Violence, Work and Reproduction, Temple University Press, Philadelphia. 